\title{
DIALOGIC ADIGA: THE NEOLIBERAL GOSPEL AND ITS CONTEXTS IN THE WHITE TIGER
}

Florian Andrei VLAD ${ }^{1}$

\begin{abstract}
Aravind Adiga's 2008 Man Booker Prize-winning novel, The White Tiger, both accommodates and provokes a variety of voices and discourses, evoking and dealing with India's past, present, and future, thus highlighting its author's dialogic vision. Although postcolonial and posthumanist approaches are worth exploring at length in this very challenging text, the current starts from the novel's initial "conversation" with a controversial non-fiction book, Thomas Friedman's The World Is Flat, and the theory of the ten flatteners that reshape globalization, with Bangalore as the then (2006) neoliberal hub of the world. Using the patterns of the frame narrative of the Arabian Nights and of the European epistolary novel, the text under investigation dramatizes and transfigures the dark side of neoliberalism by means of the imaginary conversation between a murderer turned successful entrepreneur and the leader of the world's most prominent rising economic tiger.
\end{abstract}

Keywords: dialogism, neoliberalism, postcolonial studies, globalization, outsourcing DOI: $10.24818 / \mathrm{SYN} / 2021 / 17 / 2.04$

1. A post-Pentecost Account of Speaking in Tongues: from the Apostles to Mikhail Bakhtin to Aravind Adiga's The White Tiger

The second chapter of the Acts of the Apostles in the New Testament recounts the holy moment of the Pentecost when Christ's disciples, inspired by the Holy Ghost, began speaking in tongues/ various foreign languages. This glossolalia foreshadows Christianity going global, one of the major developments of what would be called, a couple of millennia later, globalization.

In our time, in the $20^{\text {th }}$ and $21^{\text {st }}$ centuries, the Secular Ghost of neoliberalism will inspire many of those often controversial individuals that are seen as the current winners of the global economic and ideological power games. One of the winners appears to be Balram Halwai, the protagonist of Aravind Adiga's The White Tiger. Before going all the way to the above-mentioned winner of globalization, the winner of the Man Booker Prize for literature, 2008, the author of the novel prompting the peculiar glossolalia which ensues, is worth evoking here. Aravind Adiga, apart from his outstanding artistic merit, appears to be a contemporary apostle of Mikhail Bakhtin, in addition to also being a challenger of the famous economist Joseph Schumpeter and of his theory of creative destruction. Like the

\footnotetext{
${ }^{1}$ Florian Andrei Vlad, “Ovidius” University, Constanța, af_vlad@yahoo.com
} 
New Testament apostles beginning to speak in tongues at Pentecost, under divine inspiration, the author of The White Tiger both uses and provokes his audience to benefit from the uses of heteroglossia, which sounds as mystical as glossolalia, and which has become so relevant a concept in the humanities over the last few decades.

In his Problems of Dostoevsky's Poetics, Bakhtin argues that the great Russian novelist's work is essentially dialogical, unfolding on the basis of interaction between autonomous voices, as opposed to monological, where plot and character unfold within the boundaries of one single authorial world. Consequently, Bakhtin claims that attempts to approach Dostoevsky's novels from any sort of monological critical perspective will always fail to elucidate them:

A character's word about himself and his world is just as fully weighted as the author's word usually is [ ...] It possesses extraordinary independence in the structure of the work; it sounds, as it were, alongside the author's word and in a special way combines both with it and with the full and equally valid voices of other characters. (Bakhtin, 1984: 7)

However, Bakhtin's theory of dialogism or heteroglossia, arguably to be applied in various doses to all fiction, involves more than an author's voice, a narrator's voice, as well as the voices of other characters inside the fictional world. There is an increased awareness that texts, and fiction is probably the best illustration, are sites where different, often conflicting discourses interact, where heteroglossia reigns supreme. One of the texts that openly illustrate such a claim is Aravind Adiga's The White Tiger. Adiga's eminently "open text," to borrow Umberto Eco's famous concept promoted in his collection, The Role of the Reader, displays a multiplicity of facets, its heteroglossia making it approachable through a number of discourses. Its "openness" lends itself to readings of postcolonial, globalist/neoliberal, humanist and posthumanist orientations. To put it more specifically, the novel both accommodates and resists to, or challenges these discourses, which is something to be expected from far for propagandistic messages with clear, monologic discourse to convey. But then, anyway, after Bakhtin, monologism in literature is no longer a defendable thesis, and Adiga is particularly dialogic. In what follows, Adiga's dialog, at times confrontational with other voices and discourses, starts from one particular connection that has not been explored so far.

\section{Thomas L. Friedman and Aravind Adiga}

The connection between Adiga's The White Tiger and Friedman's The World Is Flat may appear to be far-fetched at first sight. Adiga's debut novel focuses on a character coming from the poorest part of India and writing, in a series of 
imaginary letters, the "autobiography of a half-baked Indian." Apparently, this is a special situation in which, anticipating the discussion of postcolonial discourse, we can imagine Adiga trying hard to make the subaltern speak, thus engaging with Spivak's famous question, "can the subaltern speak?" It looks like standard, leftwing, postcolonial literature. As for Friedman, among sociologists involved in globalization studies, most of them left-wing, critical of the negative consequences of current developments, he is a rare creature, a white tiger. He is seen as an advocate of neoliberalism, the currently prevailing discourse of globalism. Friedman's book in question here, The World Is Flat, received the Financial Times and Goldman Sachs Business Book of the Year Award in 2005, very "globalist" coordinates indeed. What on earth, whether round or flat, do the two authors have in common or what do they contribute to a discussion of the consequences of globalization?

Unlike Balram Halwai, The White Tiger's protagonist, the novel's author was born in the "India of light," in Madras, into a comfortably well-off family and soon became a citizen of the world. Judging by what his global itinerary and his allegiances amount to, he may be seen as an illustration of what Ulrich Beck calls "rooted cosmopolitanism." Raised in Australia he then went on to study at American and British elite universities (Columbia and Oxford).

Before he finished his debut novel, Adiga "discovered" his native India, working there as a correspondent for Time magazine. This is how an intelligent young man born in India and educated all over the world got to know a wide variety of people in his country of origin. Like Thomas Friedman, he also contributed articles to the Financial Times. Unlike Friedman, he was not awarded the Financial Times and Goldman Sachs Business Book of the Year Award. His main field had become literature. Instead, he got the Man Booker Prize for Fiction for The White Tiger, a couple of years after Friedman published his neoliberal manifesto, The World Is Flat.

Both Adiga and Friedman announce from the very beginning that the main character in their engagement with globalization is the emerging figure of the entrepreneur, and both find inspiration for the message in the new India which is rising as one of the prevailing Asian tigers. Weihsin Gui adds his voice to the description of the globalist narrative linking one of the complex discourses of Adiga's novel and the obvious message of Friedman's book, contributing a significant link to this narrative by mentioning another work of fiction published in the wake of the other two books in question here: Mohsin Hamid's How to Get Filthy Rich in Rising Asia. Starting from the above-mentioned Schumpeter's phrase and theory ("creative destruction"), Gui sees Adiga's and Hamid's books performing "a narrative renovation of neoliberalism's creative destruction. In so doing, they represent the expansive networks of neoliberal globalization and the actors involved in these networks" (Gui, 2013: 173).

SYNERGY volume 17, no. 2/2021 
One may slightly disagree with what Gui claims, or rather clarify what the statement actually says: Mohsin and Adiga "fictionally represent" aspects of neoliberal globalization, they far from promote the prevailing doctrine of globalization. This is where the title above also needs extra clarification, since Adiga's and Friedman's books deal with neoliberalism in apparently different ways: the former artistically representing a shocking case of a winner, Balram Halwai, the latter praising the entrepreneurial spirit of individuals who have become the champions of outsourcing and information technology. Friedman's book promotes the "sort of policies developing countries need to undertake in order to create the right environment for their companies and entrepreneurs to thrive in a flat world" (Friedman, 2006: 406).

What follows will show that the subtitle above, "Thomas L. Friedman and Aravind Adiga" actually means "Thomas L. Friedman vs Aravind Adiga," the two books promoting different perspectives on neoliberal globalization. One more common detail links a fictional Indian subaltern turned entrepreneur and an all-too-real American neoliberal, Adiga's protagonist and The World Is Flat's author, respectively. The two figures meet in Bangalore, so to speak. The former starts from India's heart of darkness and poverty and ends up in Bangalore as a prosperous beneficiary of the outsourcing that globalization has facilitated. Friedman leaves America, flies in the opposite direction in which Columbus sailed in order to find the western route to India, suspecting that the world is round. It is in the same Bangalore that Friedman has a revelation, running counter to Columbus's: the world is flat, a statement based on the theory of "the ten forces that flattened the world" in the current age of globalization. The fifth flattener, in Friedman's theory is outsourcing, which Balram Halwai proudly boasts as the engine of his thriving business. In this new world, and in this new rising India, individual entrepreneurs can successfully compete against large multinational corporations. This is what Balram the entrepreneur has achieved as shown in his far from moral "autobiography of a half-baked Indian."

\section{Some Preliminary Fictional Indias and the Post-Postcolonial} Way Ahead

In his introductory essay to Nation and Narration, Homi K. Bhabha meditates on "the impossible unity of the nation as a symbolic force" (Bhabha, 1990:1). This invites one to rephrase for our purposes the title of Luce Irigaray's This Sex Which Is Not One as "this nation which is not one." How many Indias are there as far as prevailing imagined communities go? Fictional India has moved past many notable landmarks, the $20^{\text {th }}$ century and the $21^{\text {st }}$ being the most relevant to the understanding of such novels as Aravind Adiga's The White Tiger. At the beginning of the $20^{\text {th }}$ century and at the time of India as the jewel in the imperial British crown such voices as those of the colonisers were the prevailing ones. Orientalism as exposed by Edward Said, more specifically what he calls "the codes 
of Orientalist orthodoxy"(Said, 1977: 40), can be detected in the otherwise sympathetic but patronizing discourse of E.M. Foster's A Passage to India (1924), with the mud and the filth "swelling here, shrinking there, like some low but indestructible form of life" (Forster 1924: 4) The colonizer deplores the rift between the Moslem India and the Hindi India, between "Mosque," the title of the first part of the novel, and "Temple," the title of the third and final part. In between are the mysterious, unpredictable, "oriental, tricky "Caves of Malabar." The main rift is between the very rich and the very poor in the caste-ridden "one hundred Indias," as Mrs Moore sees the huge country, where the colonizing Brits ensure that stability should prevail as their main civilizing task, echoing Kipling's "white man's burden." As a whole, the British are shown to look down on the Indians, while the subaltern Indians mistrust their British superiors.

The lowest subaltern of all, the one at the bottom of the Indian caste system, the dalit, does not appear for a long time, with the notable exceptions of M. R. Anand's book, Untouchable, published in the interwar period, and Premchand's Godaan, a novel about the Indian village poor. Toraj Gajarawala assesses Anand's novel's significance, of a text that exploits the conventions of social realism, shedding light on the Indian dalits (Gajarawala, 2009: 21). The same critic is aware that dealing with Indian poverty does not lend itself to uses of literary experimentation, of irony and satire, characteristics of what would be Adiga's debut novel's hallmark. Adkins does not find social realism as one of Adiga's preoccupations, either, his article on The White Tiger tracing the journey of the Indian novel from modernist longing to neoliberal disgust, thus introducing neoliberalism in the interpretation of the novel under discussion in this essay (Adkins, 2019: 169 - 188).

For many years, "orientalist" stereotypes defined how the Orient, later subsumed under the broader scope of the so-called third-world, as well as its prototypical subject, had been represented within Western discourse, as Edward Said notes, when discussing the "willed imaginative and geographic division made between East and West, and lived through during many centuries" (Said, 1977:202). In the meantime, the colonized subject was supposed to remain silent, in the opinion of such postcolonial thinkers as Gayatri Chakravorty Spivak. Antonio Gramsci's concept of the subaltern, referring generally to the native of any colonial territory, got a new twist in Spivak's postcolonial thinking, in which the term denotes the colonial dispossessed, the underclass excluded, unlike the elite natives, from the power games. In her famous essay "Can the Subaltern Speak?" Spivak focuses on the "lowest" of the subalterns, on the third-world subaltern woman, apparently protected by the discourse of imperialism, yet denied the choice of a significant voice (Spivak,1988: 299). Rosalind C. Morris very perceptively comments on Spivak's theory. The postcolonial critic, in the opinion of Morris, invests the same ideological position with the determination to endow both the feminine hysteric and the postcolonial subaltern with the voice that they have been deprived of. India 
is large enough to accommodate both feminine and masculine subalterns crying to be heard (Morris, 2010: 3).

As it will be seen since India has gone "postcolonial," together with what Salman Rushdie calls the "midnight children" of the country's becoming independent in 1947, the voice of the subaltern, in a very loose sense, has been heard on many occasions. In fiction, the Booker and then the Man Booker Prize has given its due to such remarkable Indian voices as Rushdie's, who was also awarded the Booker of Bookers for his outstanding work. A decade before Adiga received his own Man Booker Prize for his debut work, The White Tiger, Arundhati Roy "spoke" with her The God of Small Things (Man Booker Prize, 1997). Roy appears to contradict Spivak if seen as a third-world female subaltern. Yes, the (female) subaltern can speak very loudly, one might feel tempted to say. To be fair, though, the characters in The God of Small Things are Indian, but hardly subaltern, belonging to the reasonably affluent class, but the voices of that vast subcontinent may be associated with the overall, conflicting discourse in which the subalterns are trying to have their voices heard. Balram Halwai, as it turns out, starts his fictional itinerary from the position of the subaltern in a more obvious fashion than Arundhati Roy or Anita Desai's characters.

India is a country of dramatic contrasts, and Adiga will be the next author to take the discussion of the subaltern voice even farther, into the age in which the former colony is aspiring to supremacy in the world of globalization. Significantly, even the Booker is gradually getting globalized. If, initially, it was aimed at British authors and to authors of the countries of the former British Empire, it is now available for anyone writing fiction in English (seen as a global language). The subaltern voices, so to speak, have become just as audible as British voices and voices of the English-speaking world as a whole.

Following Balram and simplifying the complexity of the country, there are two Indias, "its heart of darkness" being a land of desolation and poverty, equally blessed and cursed by the Ganga. In dark India, the protagonist is a nobody, who might end up like all the members of his family, like his unfortunate mother. One of the first flashbacks pervading the narrative evokes Balram's mother's funeral, the young child's first traumatic experiences. The mother's burning body appears to reluctantly go into the dirty mud of the Ganga, which is likely to eventually suck all the lower caste people into misery and oblivion after lives of humiliation and suffering. These subalterns, both men and women, have no voice, as Spivak so memorably claims. Not only does the young protagonist lack a significant voice, like many others around him, he does not even have a name, to say nothing about a birthday. People, including his family, simply call him Munna (boy).

In the opinion of Lena Khor, not only does the subaltern Balram acquire a voice, he will identify the problem of inequality and oppression and will correct the 
situation. Starting from Spivak's question, Khor will, in her turn ask a question, "can the subaltern right wrongs?" She appears to see in the terrible act that Balram perpetrates out of utter despair an indication of some sort of social justice. She sees Adiga's protagonist, "a poor subaltern, to identify the problem of the rich growing richer at the expense of the poor as the most egregious wrong, and to right this wrong" (Khor 42). It is easy to dismiss Khor's statement: Balram does not right a wrong by killing Mr Ashok, much in the same way in which Sethe in Morrison's Beloved does not right the wrong of the horror of slavery by killing her precious baby. The two authors start from extreme situations and try to imagine extreme decisions in memorable narratives.

However, the beginning of Adiga's novel does not show the protagonist in the situation of a subaltern facing an all but impossible situation. It places the former anonymous, "speechless" boy into one of the most prominent positions in a new India and in the world, at least in the story that he tells as the novel's narrator. Balram is now a successful businessman in a completely new and dynamic India, in Bangalore, lecturing the Chinese Premier about entrepreneurship. Balram's "entrepreneurial India" and Wen Jiabao's China, in the opinion of the former subaltern Munna, represent the future, while the West is the past. However, as a close reading of the novel in connection with a host of converging and diverging voices and discourses is bound to reveal, Adiga's novel is more than a monologic allegory of "new" India making its spectacular entry into capitalism. Betty Joseph refers to Fredric Jameson's essay, "Third-World Literature," in which the critic expresses his "Orientalist credo" that all third world texts assume a straightforward allegorical shape because their countries of origin broke into the capitalist system "without western cultural markers such as the private-public debate" (Joseph, 2012: 68). If The White Tiger is to be read allegorically, should Balram be seen as a representative of this new India? To what extent is this a narrative about India and to what extent is it a story about the opportunities and problematics of neoliberalism, as Betty Joseph wonders in her own essay, "Neoliberalism and Allegory"? The text, woven in its intertextual web, ironically suggests what Thomas Friedman had just proclaimed in his The World Is Flat: go to the new India of downtown Bangalore and Mumbai if you want to see what the future of the "flattening world" is all about. This is, obviously, a post-post-colonial India, a far cry from the India of darkness, where Balram, the son and grandson of a long succession of colonial subalterns, had been born.

\section{Teaching the Entrepreneurial Neoliberal "Fables of the Tiger Economy": Balram Writing to Wen Jiabao}

The phrase "fables of the tiger economy" belongs to Sundhya Walther. In her perceptive article on species and subalternity in Adiga's novel, Walther describes Balram as, far from a subaltern, "an animal figure, an embodiment of the predatory power of contemporary Indian and global capitalism (Walther 2014:579), in one of 
these fables of the tiger economy. This supports the previously mentioned Betty Joseph and her observation about neoliberalism and allegory stated in her 2012 article. China and India are prominent among the Asian tigers, but Balram sees himself as unique, as the white tiger, not only predatory, but also very rare.

The format of an epistolary novel is made obvious from the beginning of the narrative, and the addresser and addressee appear to be prominent representatives of two Asian tiger economies, at least in the opinion of the imaginary letter writer, Balram Halwai. The formal format of the letterhead of the imaginary business letter mentions as the letter's recipient and address "His Excellency Wen Jiabao, The Premier's Office, Beijing, Capital of the Freedom-Loving Nation of China." The writer/ protagonist/ narrator styles himself as "the white tiger" of the novel's title, a thinking man and an entrepreneur, while his address sounds equally grand: he lives "in the world's centre of technology and outsourcing Electronics City Phase 1 (just off Hosur Main Road), Bangalore India." (Adiga, 2008: 3). He had been there for a couple of years, an important entrepreneur undoubtedly glimpsed by Thomas Friedman during his Bangalore revelation recounted at the beginning of his The World Is Flat.

In the already mentioned highly dialogic fashion that the novel assumes, the European epistolary subgenre meets with the Oriental framed stories narrative brought to the West by $18^{\text {th }}$ century Orientalists under various names such as Arabian Nights or One Thousand and One Nights. Various selections of those collections and various translations in French, German, English, promote different interpretations of the countries of origin from the Muslim Middle East to India and China. Edward Said could have paid more attention to this collection of Oriental tales describing power and subalternity before the Europeans intervened.

If in these tales one finds a sadistic serial killer that beats Dracula. King Shahryar, reigning over the islands or peninsulae of India and China, keeps executing one wife after another. Sheherazade will put an end to the serial killing by "the power of the female subaltern" to speak and keep the king interested in the narrative marathon that extends over one hundred and one nights, until the killer has been downgraded to the status of the passive and appreciative listener.

Aravind Adiga himself is aware of the power of the framed narrative. After all, the Arabic text of the Arabian Nights was central to (Muslim) Indian culture, having been first published in full in Calcutta in the first half of the $19^{\text {th }}$ century. The White Tiger displays a different communication situation, but the frame is the same as in the Arabian Nights. Balram's neoliberal story for the benefit of his (imaginary) Communist interlocutor extends over a limited series of nights, completed by a couple of early mornings. This is just enough to fill up a 321-page paperback, worthy of the Man Booker Prize in reformed, postcolonial Britain.

The irony of the communication event between the Chinese premier and a selfstyled white tiger from Bangalore, headquartered just off Hosur Main Road, 
becomes obvious from the letterhead beginning the novel's first letter. Dark and light humor, irony and satire at the crossroads of Adiga's authorial voice and Balram's narratorial one will contribute to making an otherwise terrible and horrible story highly enjoyable, both a page-turner and a critically acclaimed novel. Unlike Sheherazade, who apparently relies only on her narrative skills to stay alive one more night, Balram the Indian tiger has something much more valuable to sell to the Chinese tiger than an otherwise gripping story.

It all starts within the framework of one fable of the tiger economy, involving India, China, and the Western world, where the emergence of the fittest and strongest is the rule in the contemporary globalization gladiatorial games. Although China, in the opinion of Balram, appears to be ahead of India in almost every way, there is something crucial missing, which the Chinese need to acquire, and India and the central figure in The White Tiger may come up with the solution. The neoliberal Indian tiger puts it clearly in one sentence which, satirically, both downgrades and extolls his nation's merits, and which is worth quoting in full: "And our nation, though it has no drinking water, electricity, sewage system, public transportation, sense of hygiene, discipline, courtesy, or punctuality, does have entrepreneurs" (Adiga, 2008:4).

Balram will offer, "free of charge," his life's story to enlighten the Chinese premier. After all, Balram and Wen Jiabao are, in the opinion of the former, the emblematic figures of the two nations that stand for the future of the world, "now that our erstwhile master, the white-skinned man, has wasted himself through buggery, mobile phone usage, and drug abuse" (Adiga, 2008: 6). Like the freedomloving nation of China, about which the semi-literate Balram had read a book once found on the pavement of a secondhand book market, the protagonist will show how he who was once a nobody became somebody.

His personal identity narrative becomes enmeshed in a comprehensive allegorical fable in which India is seen in animal terms, moving from the situation of the animals in the colonial zoo to the postcolonial, equally oppressive, but much fiercer, Rooster Coop, where mere survival, not social mobility or business promotion, beats even the toughest classical liberalism of the laissez-faire age of the developed European world. The poor orphan Munna will manage to get out of the Rooster Coop at the cost of having most of his relatives killed as reprisals of his own murderous deed. The landlords from which he manages to get free, the relatives of Mr Ashok, are also symbolically known as the predatory Wild Boar, the Mongoose, the Stork, associated with animal ferocity, inviting reading the prevailing neoliberal fable in terms associated with critical animal studies. Balram claims that his father, before he died "like a dog," had wanted his son to be treated as a man, one day, not like a caged animal in the terrible "Rooster Coop." As he conveys his story to the Chinese premier, the protagonist appears to lecture him on one particular asset that an entrepreneur has to have: being able to survive in the savage neoliberal jungle at all costs, without any scruples. 
The itinerary from poor, rural Laxmangarh to Delhi to Bangalore, from Dark India to the India of Light, from subalternity to entrepreneurial sovereignty, from the "Rooster Coop" to individual freedom undergoes a series of dramatic transformations, involving dissimulation, hypocrisy, cunning, temporary admiration followed by disdain for his employer. Then comes what the former servant sees as almost the sacrificial murder of the master and assumption of the deceased's identity under the composite name of "Ashok Sharma, The White Tiger", as the last letter, The Seventh Night, is signed. Mr Ashok had to die, Balram the neoliberal thinks, as he, who had come from America with very progressive ideas, had become corrupted by the business and political environment in which he had to live. He had become weak, unable to survive in India. Balram apparently motivates cold-blooded murder largely out of respect for the previous image of his master (as well as out of despair). He thinks he has to kill his master and take over "the civilizing mission" of neoliberalism as he understands it, a halfbaked Indian entrepreneur.

This civilizing mission will be undertaken by Balram when he is a rich businessman away from the Dark India controlled by the likes of the Wild Boar, the Mongoose, the Stork, who grease the wheels of both competing political parties at election times. The old, antiquated corrupted system has to die, so that "creative destruction" can move business forward into a new age and a new space. Bangalore is central to one of these new spaces, standing for the future. Balram, turned into Mr Ashok Sharma, does not have servants, but employees, whom he treats fairly, while also preserving the dishonest practices of his previous masters in his dealings with politicians and the police. Are murder and corruption part of the neoliberal series of lectures freely and generously given by Balram to his equal, the Chinese premier? Obviously not. The terrible tale of his feigned humility, dishonesty, lack of solidarity, as well as his acquired taste for corruption, the murder of the "least evil animal," $\mathrm{Mr}$ Ashok, is meant, by Balram, to counterbalance the official story about how saintly and moral India is, which Wen Jiabao will be told when he pays his official visit to Bangalore, the world's centre of technology and outsourcing.

\section{Conclusion}

Aravind Adiga as a novelist who orchestrates a polyphony of voices does not aim to assume the obvious position of a moralist who castigates India's mores and its troubled heritage of injustice and suffering, although glimpses of what is metaphorically referred to as the Rooster Coop features prominently. The precolonial caste system is still there all right, although Balram tends to see it changing in a new world run by entrepreneurs transcending the caste system, or simplifying it to the extreme. The limited panorama of people afflicted by poverty and oppression does not show illustrations of solidarity among what Franz Fanon called "the wretched of the Earth," with Balram as untypical of these people. 
Balram is not the typical Indian subaltern, he is unique, he is a monster. The novel does not faithfully represent the life of poor people in India. It is a novel which, like Morrison's Beloved, like Sapphire's Push, like Nabokov's Lolita, invites readers to get out of stereotypical thinking.

Through the "artistic manipulation" of the intersecting discourses that the author enables, the Neoliberal Gospel that Balram preaches for the benefit of his highranking interlocutor, reveals its most sinister dimension seen by the protagonist as blind necessity. Far from being a novel to be read in a realist tradition, through its artifice and dialogism, The White Tiger invites interpretations from a variety of perspectives, and, although professedly undidactic, appears to indirectly teach by terrible, negative example while, apparently paradoxically, redeeming the bleak picture of its fictional world through the acrobatics of irony and dark humor. Among the important voices left out of this limited discussion of the novel's contemporary relevance is that of film director Ramin Bahrani. The book published in 2008 was dedicated to him. Bahrani's film version of the book was released in early 2021. The special relationship between the novel and the film is worth investigating. For the time being, even what is being left out, as far as significant contexts go, is significant in its own right.

\section{References and bibliography}

Adiga, A. 2008. The White Tiger. London: Atlantic Books.

Adkins, A. 2019. "Neoliberal Disgust in Aravind Adiga's The White Tiger," in Journal of Modern Literature, Spring issue: Reading a Century of Affects: From Modernist Longing to Neoliberal Disgust 42(3): 169-188.

Bakhtin, M. 1984. Problems of Dostoevsky's Poetics. Ed. and transl. by Caryl Emerson. Introduction by Wayne C. Booth. Minneapolis and London: University of Minnesota Press.

Bhabha, H. 1990. "Introduction: Narrating the Nation," in Nation and Narration, ed. Homi Bhabha, London and New York: Routledge.

Forster, E.M. 1924. A Passage to India. San Diego/New York/ London: Harcourt, Inc.

Friedman, T.L. 2006. The World Is Flat: The Globalized World in the TwentyFirst Century. Updated and Expanded. London and New York: Penguin.

Gajarawala, T. 2009. "The Last and the First," in Economic and Political Weekly, December 12-18 issue, 44 (50): 21-23.

Gui, W. 2013. "Creative Destruction and Narrative Renovation: Neoliberalism and the Aesthetic Dimension in the Fiction of Aravind Adiga and Mohsin Hamid," in The Global South, Fall issue Dislocations, 7 (2): 173-190.

Joseph, B. 2012. "Neoliberalism and Allegory." Cultural Critique, 82: 68-94.

Khor, L. 2012. "Can the Subaltern Right Wrongs?: Human Rights and Development in Aravind Adiga's 'The White Tiger"' in South Central Review, 29 (1/2): 41-67. 
Morris, R.C. 2010. "Introduction." In Rosalind C. Morris (ed.) Reflections on the History of an Idea: Can the Subaltern Speak. New York: Columbia University Press: 1-20.

Said, E. 1977. Orientalism. London: Penguin.

Spivak, G.C. 1988. "Can the Subaltern Speak?" in Cary Nelson and Lawrence Grossberg (Eds.) Marxism and the Interpretation of Culture. Houndmills, Basingstoke, Hampshire and London: Macmillan: 271-316.

Walther, S. 2014. "Fables of the Tiger Economy: Species and Subalternity in Aravind Adiga's The White Tiger", in Modern Fiction Studies, 60 (3): 579-598.

\section{The author}

Florian Andrei Vlad holds an M.A. in American Studies from the University of Heidelberg and a Ph.D. from "Ovidius" University, Constanța, in whose Faculty of Letters he teaches British and American literature. His first book-length volume on American fiction, based on his Heidelberg MA thesis, Fictional Americas at War, was published in 2006. After defending his PhD thesis, New Flesh, Old Demons, on representations of contagion in American literature, he went on to co-author a book on British literature - British Gothic and Its Travelling Companions (2016) and one on American 19th century: Literary Selves and Identity Narratives in the First American Century (2017). His latest books are Rewriting the American Culturescape and Space, Place, Narrative in John Quinn's Poetry (both at Editura Universitară, 2020). 